\title{
Going "beyond food": Confronting structures of injustice in food systems research and praxis
}

\author{
Catarina Passidomo, * University of Georgia
}

Submitted June 17, 2013 / Published online August 12, 2013

Citation: Passidomo, C. (2013). Going "beyond food": Confronting structures of injustice in food systems

research and praxis. Journal of Agriculture, Food Systems, and Community Development, 3(4), 89-93.

http://dx.doi.org/10.5304/jafscd.2013.034.009

Copyright (C) 2013 by New Leaf Associates, Inc.

\begin{abstract}
This commentary argues for a need to go "beyond food" in research, writing, and activism on the food system. Noting a tendency within both academic and activist discourse around food to focus on "the food itself," rather than on broader structures of inequality and disinvestment, I argue that more research is needed that focuses explicitly on the ways in which institutional structures and systems (including nonprofits, schools, housing, as well as the food system) can exacerbate broad injustices, including limited food access. I draw on research experience in post-Hurricane Katrina New Orleans, USA, as well as commentary from eminent food systems scholars, to advocate for new research trajectories that utilize food as a lens
\end{abstract}

\footnotetext{
* Department of Geography, University of Georgia; 210 Field Street, Athens, GA 30602; cpassi@uga.edu
}

for contesting broader structures of injustice, rather than advocating for more and better food as an end in itself.

\section{Keywords}

food justice, New Orleans, race, whiteness

\section{Introduction}

At the 2013 annual meeting of the Association of American Geographers (AAG), a panel of eminent food systems scholars gathered in a crowded room in a Los Angeles conference center to debate whether it is time to move "beyond food" in our research and activism. The panel, organized by Lindsay Naylor ${ }^{1}$ and consisting of food scholars Jessica Hayes-Conroy, ${ }^{2}$ Aaron Bobrow-Strain, ${ }^{3}$

\footnotetext{
${ }^{1}$ University of Oregon

${ }^{2}$ Hobart and William Smith Colleges
} 
Julie Guthman, ${ }^{4}$ Susanne Freidberg, ${ }^{5}$ Alison Hope Alkon, ${ }^{6}$ and Daniel Block, ${ }^{7}$ was prompted to discuss whether, and to what extent, food (as both a product of capitalist systems and a system in itself) can serve as a lens for exposing and examining key issues (including labor, immigration, corporate consolidation and personhood, gender equity, and indigenous rights, among others) that are often obscured or overlooked when the focus is on "just food." There was general consensus among the panelists that research on food systems has accelerated in the past decade, roughly keeping pace with popular and activist interest in making food systems more accessible, healthful, fair, and just. Panelists also agreed that academic interest in food systems has tended to celebrate emergent and flourishing "alternative food movements" that are embedded in local communities, support and grow local economies, and side-step (lacking the power to diminish) the environmental and social costs associated with globalized/corporate/industrial agriculture. Citing evidence for popular support, particularly within certain demographics, for particular "kinds of foods" proffered through these alternative networks, studies of non-alternative food systems have been rare. Furthermore, going "beyond food" means considering seriously all of the other systems that are shaped by and reflect hegemonic ideologies; or, working in reverse, perhaps it is time to start thinking of food (systems) as a lens through which systems, structures, and institutions of dominance are made visible and, subsequently, contestable.

So, why go "beyond food"? And, for that matter, why start with food? I will address the first question second, by drawing on personal research experience with food justice activism in the city of New Orleans. I will suggest a need for more and deeper critical investigations of the influence of what Alkon and McCullen (2011) have called an "affluent, liberal habitus of whiteness" within alternative food system praxis (and research, for

\footnotetext{
${ }^{3}$ Whitman College

${ }^{4}$ University of California, Santa Cruz

${ }^{5}$ Dartmouth College

${ }^{6}$ University of the Pacific

${ }^{7}$ Chicago State University
}

that matter). I will also report back from the AAG panel on "beyond food," which suggests some related possible research trajectories.

First, saying nothing of going "beyond" them, why study food systems, in and of themselves, at all? There is obviously considerable and growing academic and popular interest in various aspects of (the) food system(s). The panel described above was just one of 46 panels and paper sessions at the 2013 AAG meeting sponsored by the nascent Food and Agriculture Specialty group, which itself was formed just two years ago and grew from 10 members to over 150 during the past year. Growing interest is evident in other disciplines as well, from nutrition and public health, to sociology and anthropology, and urban and environmental studies; perhaps even more telling are the numerous departments and interdisciplinary programs in "food studies" popping up in colleges and universities both nationally and internationally (see Hilchey, 2012).

Scholars and popular authors have charted and critiqued a variety of food-related movements, which represent a range of interests and priorities - from human health (Lang, Barling, \& Caraher, 2009; Nestle, 2002) and social justice (Gottlieb \& Joshi 2010) to environmental sustainability (Perfecto, Vandermeer, \& Wright, 2009), animal welfare (Singer, 2009 [1975]; Safran Foer, 2009), and food sovereignty (Wittman, Desmarais, \& Wiebe, 2010), among others. These movements advocate on behalf of farmers, on behalf of consumers, on behalf of seeds, animals, fish, and soil. They often attempt to restructure power relations, to question and combat the authority of multinational corporations and the states that band with them to dominate the form and flow of agricultural inputs and edible outputs around the globe (Holt- Giménez \& Patel, 2009). Within this framework, the discourse surrounding urban gardening and other forms of urban food justice work is often laden with messages of personal responsibility and individual empowerment, and often neglectful of the structural causes of food insecurity and hunger (Pudup, 2008).

Specifically, the flourishing of academic interest in food systems over the last decade has resulted in lamentably little attention to how race 
and racism intersect with food activism, or with food systems more broadly. While there has been some attention to the connections between systemic and structural racism and the landscape of contemporary food systems, which, like other manifestations of racialized capitalism, generate spatialized constraints on food access, there has been less attention to the overwhelming whiteness of the movement for food justice, even as that movement "works" to address injustices in communities of color. Julie Guthman (2008) and Rachel Slocum (2007) are notable exceptions. Both authors argue that "the food itself"-specifically the quantity and quality of food available in lowincome communities of color-tends to galvanize and animate white people; for people actually residing in those communities, however, "the paucity of quality food in their communities is seen as evidence of [a] lack of [political and economic] power" (Block, Chávez, Allen, \& Ramirez, 2011). This discrepancy in identifying the problem reflects, in many ways, the difficulty that inheres in seeking solutions, and may begin to explain why food justice projects aiming to promote social justice, or, more specifically, to increase healthy food access for people of color, so often fail to address the underlying systems and structures that helped create the unjust food landscape that characterizes American cities.

\section{Beyond Food}

To make the case that more research and praxis ought to consider processes and practices that go "beyond food," I draw on findings from my own research of and with food justice activism in postHurricane Katrina New Orleans. This research investigated the emergence and flourishing of grassroots efforts to envision and enact a more socially and economically equitable landscape of food access. Its primary goals were (1) to investigate the extent to which food justice and food sovereignty discourses and activism interact with and affect the material and social realities of the frequently low-income communities of color in which they are situated; and (2) to examine whether such activism helps or hinders pre-existing efforts to alleviate hunger, acknowledge and address racism, and promote social justice at the scales of the neighborhood and of the city. Through a oneyear period of ethnographic research, I was able to draw a few conclusions, which suggest a need to consider (explicitly) the broader structural forces that compel food justice projects in the first place. First: the self-proclaimed "success" or "failure" of urban agriculture and other food justice projects to address concerns regarding food access and hunger (or, conversely but relatedly, obesity) relies on a complex matrix of factors, including the race and nativity of the project organizers (i.e., whether or not they are from New Orleans), the sense of mutual social and cultural understanding among project organizers and community residents, and project organizers' ability to examine and confront historic and contemporary legacies of racism and structural inequality. The relatively recent and acute disaster of Hurricane Katrina in 2005 has made these structural inequities more visible on the landscape, but has not necessarily facilitated robust power analyses among those individuals who have come to help the city rebuild. Such analyses of how power is distributed throughout organizations and communities, coupled with historical analyses of structural racism and urban disinvestment, are crucial to any project or programming concerned with food access in poor communities. More research is needed on successfully executed power analyses and, conversely, on what happens when organizations or institutions promoting "food justice" struggle or fail to come to terms with racial and class inequities. Rosing (2012) offers potential paths forward in this regard, suggesting that academics and activists embarking on food systems development embed that work within a social justice framework prior to initiating projects in lowincome communities.

Second, spatial patterns of food access in the city of New Orleans verify the existence of socalled "food deserts" in which residents of lowincome neighborhoods struggle to access fresh food proximate to where they live. Because food access is a prominent concern and has gained national recognition, community residents who engage in political struggles to increase food access are likely to feel empowered to demand other changes that would improve their health and livelihoods. Specific grassroots efforts to increase 
food access may succeed not only in changing the "foodscape," but also in enhancing civic participation and community activism more broadly, on a range of social issues. For this reason, I argue, it is imperative that food justice activism be generated within communities of need, rather than imposed on them by well-meaning outsiders. More research is needed on the role of grassroots food activism for promoting, enabling, or enhancing broader civic participation among disinvested communities.

In addition to the research priorities that emerged through my own investigations in New Orleans, panelists from the AAG panel on "Beyond Food" suggested compelling avenues for moving beyond food in our research and writing on the food system and its various components. First, generally speaking, researchers must be constantly vigilant in questioning how products of our work may be "captured" to generate outcomes that we may deem undesirable or unjust. Second, we must remain cognizant of the ultimate goal of our research, which may sometimes mean that we pursue research trajectories that do not immediately appeal to us in the way that much ethnographic study of alternative food systems has. As Susanne Freidberg noted at the AAG forum, food can be both a gratifying and a pleasurable thing to study, particularly when our research sites are farmers' markets or other pleasant spaces. What may be less appealing, however, and yet are arguably more important at this stage, are studies of corporate and state actors who shape the dominant food system. Alison Alkon asked us to consider what "purchase" food can give us in studies of racial formation, labor and immigration policies and practices, gender politics and performativity, the creation of and contestation around public space, and the formation of policies that facilitate or constrain civic participation and democratic ideals. In other words, how can we research (and complicate, contest, or qualify) these broader social questions through food? Jessica Hayes-Conroy offered other examples of how food and its associations might serve as a useful analytical lens, thinking through food to examine bodily physicality and biopolitics; the social construction of and political investment in "health" and wellness; and the ways in which social difference is produced and reproduced both discursively and materially.

In a related theme, Aaron Bobrow-Strain argued that critical analyses using food can help to "explode the fiction of the sovereign individual," while simultaneously exposing the limits of neoliberal and/or narrowly conceived "food justice" efforts. As it is currently conceived, Bobrow-Strain argued, food studies is a "public intellectual project." While this may be fine, we could, and perhaps should, consider studies with greater social impact. In this vein, Bobrow-Strain suggested "studying up" the corporate food chain. Rather than continuing to frame "Big Ag" as an abstraction, it is time to critically and thoroughly examine how power is constructed, negotiated, and maintained within the dominant food system. Julie Guthman agreed, pointing out that nearly all studies of food tend to focus on alternatives "relative to how most food is produced." In order to "study up," she argued, we need new methods and new questions; while it may be enjoyable and personally rewarding to conduct participant observation studies at farmers' markets and community supported agriculture operations (CSAs), new theoretical and methodological approaches are needed to study both "Big Ag" and "agriculture of the middle."

\section{Conclusion}

There is considerable and growing momentum in the study and practice of food systems. Work that has focused on food and agriculture as means and ends in themselves should be celebrated for the substantive changes it has made possible, and for broadening and deepening critical interest in and engagement with both dominant and alternative food systems. Now, drawing on that momentum, it is time to proceed cautiously in our research and activism by considering the broader implications of that work as well as the systems and institutions in which it is situated. I, along with many others, have argued for a need to go "beyond food," through research that positions food as a lens through which pressing social and political issues and processes may be critically examined. Such research can capitalize on popular interest in and activism around concerns regarding food, but 
should take food as a starting point, rather than an end in itself. Borrowing suggestions from eminent food systems scholars and from my own research experience, I have offered a few possible research trajectories for both scholars and practitioners interested in understanding the limitations of traditional food systems research and in moving beyond those limitations to unveil and contest entrenched ideologies and power structures within food and the many systems and institutions with which it is connected.

\section{References}

Alkon, A. H., \& McCullen, C. G. (2011). Whiteness and farmers markets: Performances, perpetuations... contestations? Antipode, 43(4), 937-959. http://dx.doi.org/10.1111/i.1467-8330.2010. 00818.x

Block, D. R., Chávez, N., Allen, E., \& Ramirez, D. (2012). Food sovereignty, urban food access, and food activism: Contemplating the connections through examples from Chicago. Agriculture and Human Values, 29(2), 203-215. http://dx.doi.org/10.1007/s10460-011-9336-8

Gottlieb, R., \& Joshi, A. (2010). Food Justice. Cambridge, Massachusetts: MIT Press.

Guthman, J. (2008). "If they only knew": Colorblindness and universalism in California alternative food institutions. The Professional Geographer, 60(3), 387-397. http://dx.doi.org/10.1080/00330120802013679

Hilchey, D. (2012). Higher education and food systems: A tentative but growing relationship. Journal of Agriculture, Food Systems and Community Development, 2(3), 1-3. http://dx.doi.org/10.5304/jafscd. $\underline{2012.023 .019}$
Holt-Giménez, E., \& Patel, R. (2009). Food rebellions: Crisis and the hunger for justice. Oakland, California: Food First Books.

Lang, T., Barling, D., \& Caraher, M. (2009). Food policy: Integrating health, environment and society. Oxford: Oxford University Press. http://dx.doi.org/ 10.1093/acprof:oso/9780198567882.001.0001

Nestle, M. (2002). Food politics: How the food industry influences nutrition and bealth. Berkeley, California: University of California Press.

Perfecto, I., Vandermeer, J., \& Wright, A. (2009). Nature's matrix: Linking agriculture, conservation and food sovereignty. London: Earthscan.

Pudup, M. B. (2008). It takes a garden: Cultivating citizen-subjects in organized garden projects. Geoforum, 39(3), 1228-1240. http://dx.doi.org/10.1016/i.geoforum.2007.06.012

Rosing, H. (2012). Demystifying the local: Considerations for higher education engagement with community food systems. Journal of Agriculture, Food Systems, and Community Development, 2(4), 79-84. http://dx.doi.org/10.5304/jafscd.2012.024.005

Safran Foer, J. (2009). Eating animals. New York: Little, Brown and Company.

Singer, P. (2009 [1975]). Animal liberation. New York: Harper Collins.

Slocum, R. (2007). Whiteness, space and alternative food practice. Geoforum, 38(3), 520-533. http://dx.doi.org/10.1016/j.geoforum.2006.10.006

Wittmann, H., Desmarais, A., \& Wiebe, N. (2010). Food sovereignty: Reconnecting food, nature and community. Oakland: Food first. 